\title{
マルチエージェント技術を用いた広域環境向け 個人間分散バックアップシステムの開発†
}

\author{
打矢 隆弘*
}

\section{1. はじめに}

近年, インターネットの普及に伴い, 情報の電子化が急速に 進んでいる。個人情報や社内情報などの重要な情報も電子化さ れており，データの消失に備える必要がある。デー夕消失の原 因として, ユーザ誤操作, 計算機故障, コンピュータウイルス の感染などがある。そのため, データの消失を未然に防ぐため のバックアップの需要が高まっている．現在，バックアップ手 法はデー夕の保存先によって 2 種類に分類される. 1 つ目は, USB メモリや HDD / SSD な゙ののーカル環境へデータを保 存する手法である. 2 つ目は, ネットワーク上に存在するオン ラインストレージやサーバなどの分散環境へデータを保存する 手法である。しかし，それぞれの手法には問題点が存在する. ローカル環境へデータを保存する場合，災害発生により全ての データが消失する危険性がある。また，分散環境へ保存する場 合，保存容量に制限が存在したり，データの維持により維持費 が発生する。上記で述べた問題点を解決するためには，ネット ワーク環境の違いや利用者の要求などに柔軟に対応できるシス テムの構築が必要である。柔軟なシステムを実現する技術とし て，エージェント技術に注目が集まっている。エージェント技 術とは，エージェントが人，外部環境，他エージェントとの相 互作用により自律的に動作するものである。我々は，エージエ ント技術を用いて，上記で述べた問題点の解決を目標とするシ ステム第 1 版 [1] を作成した。 このシステムは, エージェント を用いることにより，複数の計算機にバックアップデータを分 散配置し，咒長化を施すことで，リストア時に全ての計算機を 用いることなくバックアップデータの復元を可能とするもの である。このシステムにより，既存のバックアップ手法に比べ て所要時間の短縮と即時性の向上を実現した。しかし，ファイ ルの更新に伴い, 複数回バックアップを行うにつれて, バック アップ先計算機に保存されるバックアップデータの容量が増加 するという問題点が存在する．また，バックアップ先の計算機 がリストの先頭から順に選定されるため, バックアップデータ が遠隔地の計算機に保存されず，ローカルバックアップ同様災 害の発生により全てのデータが消失する危険性が存在する。そ

Development of Wide Area Distributed Backup System for Individuals Using Multi-Agent Technology Takahiro UCHIYA
こで，第 1 版の問題点を解決し，可用性を高めたバックアップ システムを実現することを目的として, システムの拡張に取り 組んだ。提案システム第 2 版では重複排除技術を導入し，第 3 版では WHOIS サービスを活用した遠隔地サーバの自動選定を 導入した。本論文では，提案システムの設計開発及び評価実験 について述へ，提案手法の有効性を示す。

本論文は 7 章で構成される。第 2 章では, エージェントシ ステム及び重複排除手法について述べる，第 3 章では，既存の バックアップ手法について述べる，第 4 章では，開発したシス テム第 1 版について述べる。第 5 章では, 重複排除を導入した 開発システム第 2 版について述べる. 第 6 章では, 遠隔地サー バ自動選定を導入した第 3 版について述べる，第 7 章では，評 価実験における実験結果と考察について述べる，第 8 章では， 本論文のまとめと今後の課題について述べる.

\section{2. 基礎知識}

\section{1 エージェント}

エージェントとは, 人, 外部環境, 他エージェントとの相互 作用によって自律的に動作するソフトウェアである. エージェ ントの代表的な性質について説明する.

自律性：自己の行動や内部状態を制御することにより，他の エージェントや人間からの直接的な干渉を受けることなく 自律的に動作する.

社会性：複数のエージェントが 1 つのグループを構成するこ とにより，エージェント同士がお互いに協力しながら問題 を解決する。

自発性：目標の達成のために必要となる処理に対し, 能動的に 参加し，複数のエージェントと協力する.

移動性：ネットワークを介すことにより，他の計算機へ移動 し，移動先において処理を行う。

即応性：エージェントが自身の置かれた環境を認識すること により，あらゆる変化に対し素早く適切に反応する。

\section{2 エージェントシステム}

エージェントシステムとは, 複数のエージェントで組織を構 成することにより，エージェント同士で協調し，問題解決を目 指すシステムである。エージェント単体は単純な機能しか持た ないため, 問題を単純な部分問題に分割し, 各エージェントに 分担させる. そして, 解決された部分解を統合し, エージェン トシステム全体として1つの問題を解決する（図 1)。これによ 


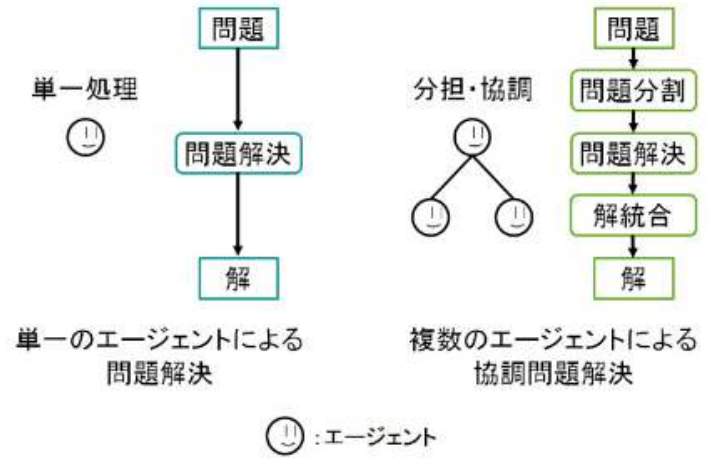

図 1 エージェントシステムにおける問題解決

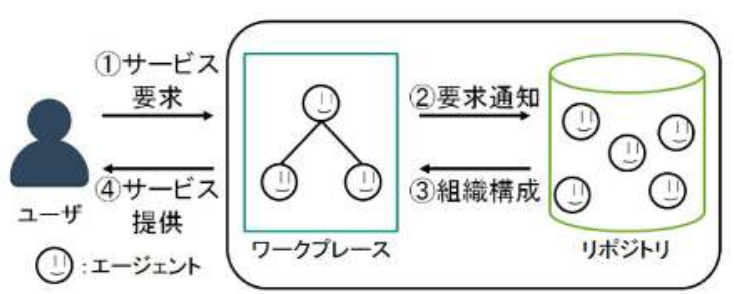

図2リポジトリ型エージェントフレームワーク

り，エージェント単体で処理する場合に比べて，処理の分散や 構造の変更が容易になるため, 柔軟性を高めることができる.

\section{3 エージェントフレームワーク}

エージェントフレームワークとは，エージェントの性質を実 現する動作環境のための枠組みである．社会性を得るための通 信プロトコルや自律性・自発性を得るための推論機構などを提 供している. 現在開発されているエージェントフレームワーク として, DASH [2]，JADE [3]， OMAS [4]，JACK [5] どが 存在しているが, この中で DASH フレームワークが最も多様 な性質を有するエージェントを開発・運用可能なことから, 本 研究ではDASH をフレームワークに採用する。

\subsubsection{DASH フレームワーク}

Distributed Agent System based on Hybrid architecture （DASH）は，エージェントを集積・管理するサーバである リポジトリとエージェントが実際に動作する環境であるワーク プレースにより構成されている。 DASH はリポジトリを基に システムの開発を行うことから, リポジトリ型エージェントフ レームワークと呼ばれる（図 2)。リポジトリに拈いてエージェ ントを管理することにより，ユーザがワークプレースに対して サービスの要求を行うと, ワークプレースがリポジトリに対し て要求を通知し、リポジトリ内で拡張契約ネットプロトコルに 基づき組織が動的に構成される，その後，エージェント組織が ワークプレース上に生成され，ワークプレース上で動作する. これにより，ユーザにサービスが提供される。

\subsubsection{DASHエージェント}

$\mathrm{DASH}$ 上で動作するエージェントは, 動作知識がテキスト ファイル内に記述されている。 DASH エージェントは, 知識

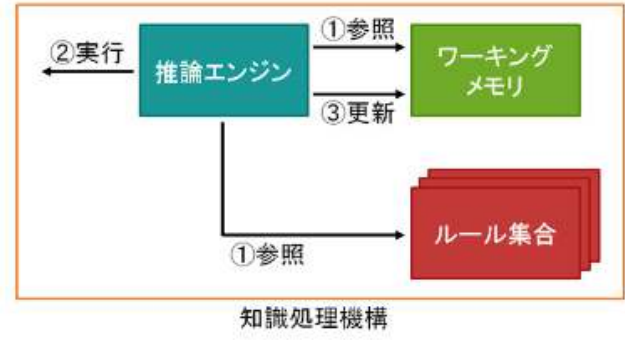

図 3 知識処理機構の内部構成

処理機構と呼ばれる自身の行動を決定する機構を有しており, ファイルの動作知識を読み込み当該機構に格納する。知識処理 機構は, 推論エンジン, ワーキングメモリ, ルール集合から構 成される (図 3). エージェントの行動手順について説明する.

1. エージェントにメッセージ/イベントが到着すると, 推 論エンジンがワーキングメモリを参照し, 発火するルー ルを検索する。ワーキングメモリには，ファクトと呼ば れるメッセージなどの知識情報が蓄積される.

2. 推論エンジンが発火可能なルールを実行する. 発火可能 なルールが複数存在する場合には, ソースコードの上部 に記述されているルールから順に実行される。

3.ルールを実行した結果, ワーキングメモリの内容が更新 され，1に戻る. 発火可能なルールがなくなった場合に 推論を終了する.

\section{4 重複排除技術}

重複排除とはバックアップ時にバックアップデータを解析 し，重複デー夕を自動的に検出して排除することにより，保存 するデータ容量を削減する技術である. 重複データとは, 既に バックアップされているデータのことである，重複排除を行う 上で, 重複排除の効果（重複排除率）を左右する最も重要なポ イントは, 下記の重複排除の単位である.

【ファイル単位】同じファイルが既にバックアップされてい たら，重複データとして排除する方式.

【固定長ブロック単位】ファイルを固定長サイズのデータ（ブ ロック）に分割し，同じブロックが既にバックアップされ ていたら，重複データとして排除する方式.

【可変長ブロック単位】ファイルをデータパターンに基づき 可変長サイズのブロックに分割し, 同じブロックが既に バックアップされていたら, 重複データとして排除する 方式.

利点：データパターンに基づいてブロックに分割するため, ファイルの更新時に新たなデータが挿入されても，ブロッ クの境界位置はほとんど変わらない (図 4). そのため, 上 記の 2 つ方式に比べて, 効率的に重複排除を行うことが できる。

欠点：ファイルのデータパターンを見る必要があるため, ファ イルサイズが増加するに伴い, 上記の 2 つの方式に比べ て，大幅に時間を要する。

本研究では, 上記の利点を考慮し, 可変長ブロック単位の重複 排除を導入する. 


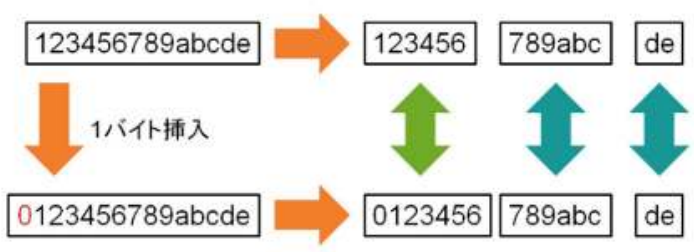

異なるブロック数: 1 個

図 4 可変長ブロック単位のファイル分割

\section{3. 既存分散バックアップ方式}

\section{1 分散バックアップ}

分散バックアップとは, 遠隔地のサーバや計算機ヘバック アップを行う手法である. バックアップ形態を 1) 個人間, 2) ク ラウド，に分類した場合，1)については，CrashPlan [6]が該 当する（但し，2018 年 10 月にサービス終了）. 2)について は，オンラインストレージサービス Dropbox [7] 等が該当す る。ユーザは専用ソフトウェアまたは Web ブラウザを用いて, ネットワークを介しデータをバックアップすることができる. Dropbox 無料アカウントでは 2 GB までのディスクスペース を利用することができ，有料アカウント（1,200 円／月）では $2 \mathrm{~TB}$ までのディスクスペースを利用することができる.

\section{2 分散バックアップの問題点}

分散バックアップシステムのユーザビリティに着目した場 合, 下記項目についての評価が必要である.

所要時間 : バックアップ開始から終了までの時間

保存容量：バックアップデータ容量の総和

即時性：ファイル更新からバックアップが終了するまでの時間 作業阻害：CPU・通信回線の占有によるユーザの作業の阻害

Dropbox の場合, デー夕転送速度が低速であることと無料利 用における容量制限があるため, 所要時間及び保存容量に課題 が残る。一方，ファイルの更新と同時にバックアップを行うこ とや, CPU 占有が少ないことから, 即時性や作業阻害について は問題がないと考える.

\section{4. 第 1 版 : 個人間分散バックアップシステム の開発}

現在，2) クラウドのオンラインストレージを用いたバック アップの利用が増加しつつあるが, 所要時間や保存容量の課題 を解決し， かつ複数の遠隔地サーバにデータを保管することで データ消失のリスクを減少する 1) 個人間分散バックアップシ ステムのニーズは依然として高い。本研究ではこの個人間分散 バックアップに焦点を当てる.

提案するシステム第 1 版は, バックアップファイルに圥長 化を施し，ネットワークに接続された複数の計算機にデータを 分散配置する (図 5)。システムはエージェントの組織として 構成され，エージェント間の連携でバックアップ処理を行う (図 6). 提案システムはエージェントの組み換えでシステムの 機能を変更できる強みを有する.

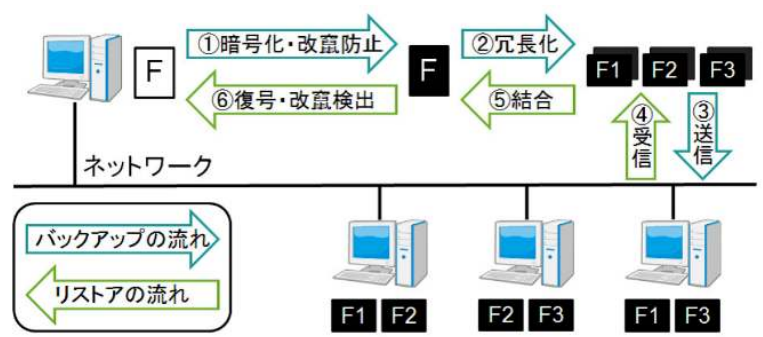

図 5 第 1 版分散バックアップシステム概要図

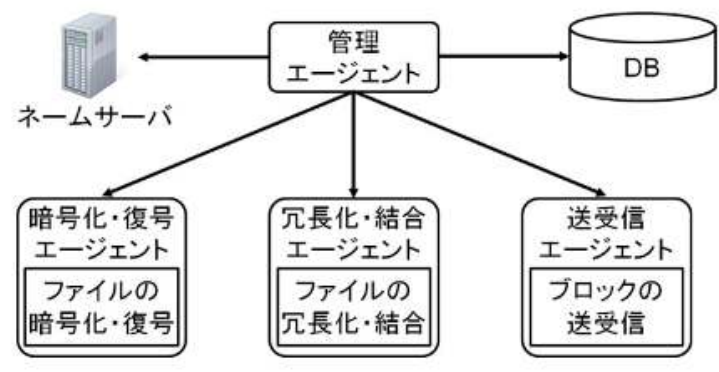

図 6 第 1 版エージェント構成図

システムの特長 1 : 暗号化・改竄防止（復号・改竄検出）

個人間分散バックアップシステムでは，元ファイルの一部の データが他人の計算機に保存されるため, データを暗号化す る必要がある。しかし, 所要時間短縮のためには, 高速なアル ゴリズムにより暗号化を施す必要がある。そのため，共通鍵暗 号である Advanced Encryption Standard（AES）を用いる。ま た，システムはネットワークに接続されており，第三者からの 不正アクセスに備え，デー夕改竄検出をする必要がある。 その ため, バックアップ時にファイルのハッシュ值を計算し，デー タベースに保存する。リストア時には各バックアップ先計算機 から送信されるブロックを統合し，生成されたファイルのハッ シュ值を計算し, データベースのハッシュ值と比較することに より, 改竄検出を行う.

\section{システムの特長 $2:$ データ冗長化}

このシステムでは，朵長化アルゴリズムとして，保存容量削 減を重視する Information Dispersal Algorithm（IDA）[8] と所 要時間短縮を重視する Simple Information Dispersal Algorithm （SIDA）[1]の 2 種類を併用する.これらの攵長化アルゴリズ ムは, $n$ : デー夕を保存する計算機数 (分散数), $m$ : 復元に必 要な計算機数 (復元必要数) としたとき, $m$ 個のデー夕を集 めれば元ファイルを復元できるというものである。これは，ブ ロックを複数の計算機へ重複配置することで可能になる．各ア ルゴリズムを用いた場合の保存容量を表 1 に示す。なお, 表中 の $|F|$ はファイルサイズである.

\section{第 1 版システムの問題点}

\section{（P1） 保存容量の線形的増加}

本システムでは，ファイルを更新するたびに更新内容に関わ らずファイル単位で保存容量が増加する，従って，複数回バッ クアップを行うにつれて線形的に増加する保存容量への対策が 必要である。 
表 1 各アルゴリズムの保存容量

\begin{tabular}{|c|c|c|}
\hline アルゴリズム & 1 計算機の容量 & 全体の容量 \\
\hline \hline IDA & $|F| / m$ & $n|F| / m$ \\
\hline SIDA & $(n-m+1)|F| / n$ & $(n-m+1)|F|$ \\
\hline
\end{tabular}

\section{(1)ファイルをパイト列に変換·先頭に固定長ウインドウを設置}

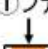
123456789abcde

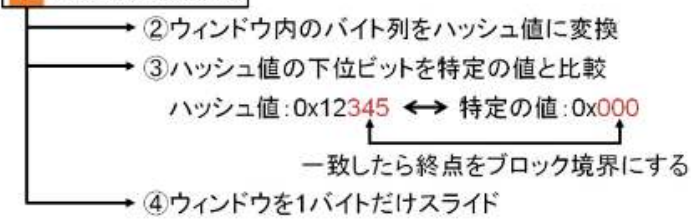

図 7 ブロックデータ分割処理 CDC の流れ

（P2）バックアップ先計算機の偏り

バックアップ先計算機は, 計算機リストの先頭から順に選定 される，そのため，バックアップ先計算機が特定の計算機へ 偏る恐れがある。これは，分散バックアップの定義に反する. 従って，バックアップ先を特定の計算機へ偏らせず，遠隔地の サーバや計算機から選定させる必要がある。

\section{5. 第2 版：個人間分散バックアップシステム の強化・拡張}

第 1 版の開発・評価を経て明らかになった課題に対し, 課題 （P1）を解決するシステムとして，第 2 版システムを開発した.

\section{1 分割・結合エージェントの拡張}

\section{システムの特長 3：重複排除に適したデータ分割}

提案システムにおいて，重複排除のためにファイルを可変長 ブロックに分割する。ここで，新たにデータ分割アルゴリズム として Content Defined Chunking（CDC）[9] を導入する．提 案システムにおけるCDC の流れについて説明する（図 7).

1. ファイルをバイト列に変換し, ブロックの境界位置を決 定するために，固定長のウィンドウを設置する.

2. ウィンドウ内のバイト列をハッシュ值に変換する．提 案システムでは, ハッシュ值を求めるハッシュ関数と して，Rabin-Karp 法 [10] を用いる，Rabin-Karp を用 いることにより，バイト列 $a_{0}, \ldots, a_{n-1}$ から求めたハッ シュ值を利用してバイト列 $a_{1}, \ldots, a_{n}$ のハッシュ值を高 速に求めることができる。

3. 変換したハッシュ值の下位数ビットを特定の值と比較す る．值が一致した場合，ウィンドウ終点をブロックの境 界とする。

4. ウインドウを 1 バイトだけスライドさせる.

5. 2.〜4.の作業をファイルの終点まで繰り返す。ファイル の終点に達したら，残りのバイト列を新たなブロックと して生成する。

以上の処理により，あるファイルの任意の部分のデータが書き 換えられたとき，ファイル全体を再度バックアップすることな く, 書き換えられた部分周辺のデータのみを対象としてバック アップを行うことができる.

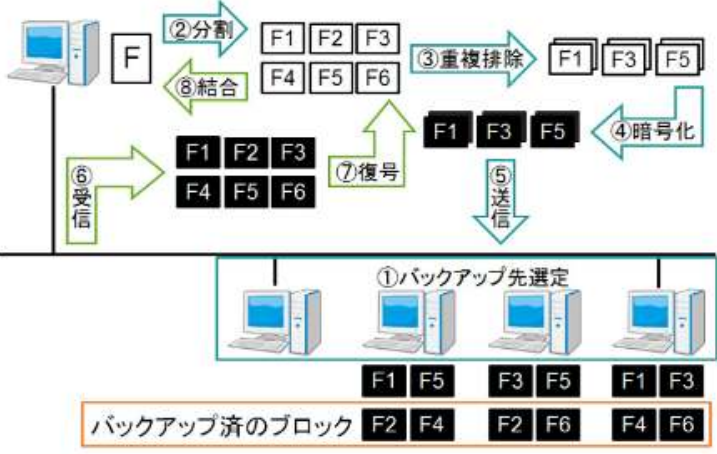

図 8 第 2 版分散バックアップシステム概要図

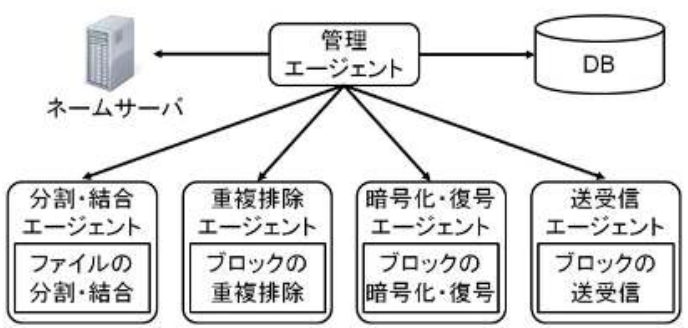

図 9 第 2 版エージェント構成図

\section{2 分散バックアップの処理フロー}

第 2 版システムは, バックアップファイルをて長化し，ネッ トワークに接続された複数の計算機にデー夕を分散配置する (図 8). システムはエージェントを用いて構成される（図 9). 以降, システムのバックアップ／リストアの流れについて説明 する。

【バックアップ処理】

1. 管理エージェントがネームサーバから環境情報を取得 し, 圥長化数や転送先計算機を決定する。 その後, バッ クアップ元計算機のファイルパスと圥長化情報を分割 · 結合エージェントへ送信する。バックアップ元計算機 のファイルパスと圥長化情報を受信した分割・結合エー ジェントは，ファイルを分割し，ブロック 1 個 1 個のサ イズをファイル（分割リスト）に書き込み, このパスを 管理エージェントへ送信する，分割リストのパスを受信 した管理エージェントは, これを重複排除エージェント へ送信する。

2. 分割リストのパスを受信した重複排除エージェントが, データベース Cassandra [11] から既にバックアップされ たブロックに関する情報を読み込む。その後, 重複排除 を行い, 重複排除後のブロック 1 個 1 個のサイズをファ イル（リスト）に書き込み，このパスを管理エージェン トへ送信する。リストのパスを受信した管理エージェン トは，これを暗号化・復号エージェントへ送信する。

3.リストのパスを受信した暗号化・復号エージェントが, ブロックに暗号化を施し，圥長化・暗号化されたファイ ル（暗号ファイル）のパスを管理エージェントへ送信す る。暗号ファイルのパスを受信した管理エージェント は，これを送受信エージェントへ送信する。 
4. 暗号ファイルのパスを受信した送受信エージェントが, バックアップ元計算機から各ファイルを該当の計算機 へ送信し，送信したファイルに関する情報を管理エー ジェントへ送信する，送信したファイルに関する情報を 受信した管理エージェントは，これをCassandra に書き 込む.

\section{【リストア処理】}

1. Cassandra からファイルに関する情報を読み込んだ管理 エージェントが，これを送受信エージェントへ送信す る。ファイルに関する情報を受信した送受信エージェン トは，該当の計算機から必要なファイルをバックアップ 元計算機に送信し，送信されたファイルのパスを管理 エージェントへ送信する。送信されたファイルのパスを 受信した管理エージェントは，これを暗号化・復号エー ジェントへ送信する。

2. 送信されたファイルのパスを受信した暗号化・復号エー ジェントが, 各ファイルに復号を施し, 復号されたファ イルのパスを管理エージェントへ送信する，復号された ファイルのパスを受信した管理エージェントは, これを 分割・結合エージェントへ送信する.

3. 復号されたファイルのパスを受信した分割・結合エー ジェントが, ファイル内のブロックを結合し, 元のファ イルを復元する

\section{6. 第 3 版 : 広域環境向け個人間分散バック アップシステムの開発}

第 3 版では, 第 1 版に存在する課題 (P2) の解決に取り組む. 本研究で提案する個人間分散バックアップシステムは, バック アップ先として遠隔地のユーザが所有する計算機を想定してい る。今回は, 遠隔地のユーザを大学の研究室所属者と想定し, 大学での利用を例として広域環境向け個人間分散バックアップ システムを実装する.

\section{システムの特長 4 : 計算機設置場所推定手法の導入}

本システムに WHOIS [12] サービスを導入することにより， 遠隔地へバックアップを行えるようにする，本研究では，IP アドレスから情報を獲得できる JPNICの WHOIS を導入する. これによりIPアドレスから大学名を特定し, 遠隔地の大学へ バックアップを行うことができる。但し，大学名だけでは遠隔 地か否かの判別はできない，そのため, Google Geocoder [13] を導入し, 大学名から緯度／経度を獲得する，大学名から緯度 ／経度を獲得することにより，バックアップ元とバックアップ 先の距離を求めることができる（図 10）。また，緯度／経度か ら距離を求めるために，下記式を用いる。このとき, 地点 $\mathrm{A} の$ 緯度 $\phi_{1}$, 経度 $\lambda_{1}$, 地点 $\mathrm{B}$ の緯度 $\phi_{2}$, 経度 $\lambda_{2}$, 地点 $\mathrm{A}$ と地点 B の角度を $x$ とする.

$$
\begin{aligned}
\cos x= & \cos \left(90-\phi_{1}\right) \cos \left(90-\phi_{2}\right) \\
& +\sin \left(90-\phi_{1}\right) \sin \left(90-\phi_{2}\right) \cos \left(\lambda_{2}-\lambda_{1}\right) \\
= & \sin \phi_{1} \sin \phi_{2}+\cos \phi_{1} \cos \phi_{2} \cos \left(\lambda_{2}-\lambda_{1}\right) \\
x= & \cos ^{-1}\left(\sin \phi_{1} \sin \phi_{2}+\cos \phi_{1} \cos \phi_{2} \cos \left(\lambda_{2}-\lambda_{1}\right)\right)
\end{aligned}
$$

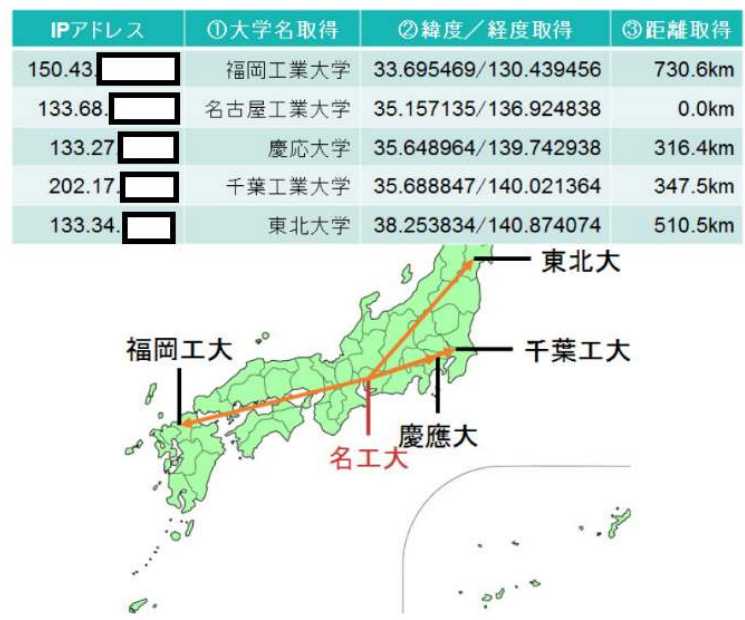

図 10 WHOIS 及び Google Geocoder を用いた距離判定

2 点間の距離 $L$ は地球の半径を $R$ とすると式 $L=R x$ により 求めることができる.

\section{システムの特長 5 : バックアップ先計算機の選定手法の導入}

提案システムにおいて, WHOIS を導入することにより, バッ クアップ先計算機の偏りをなくす。しかし，大学間の距離のみ を考慮すると, 最も遠い北海道や沖縄県の大学へ偏る恐れが ある. そのため, 大学間の距離以外に計算機のドライブ容量を 考慮することにより, バックアップ先計算機の偏りをなくす。 バックアップ先計算機の選定手法について説明する.

1. バックアップ元のユーザがバックアップ前に分散数 $n$ を 設定する.

2. 各計算機の位置情報を求め, 遠隔地（ローカルから $120 \mathrm{~km}$ 以上離れた場所）の計算機をバックアップ先候 補に選定する。

3. データベース Cassandraより選定された各計算機の累計 バックアップ回数を求め, 累計バックアップ回数の少な い計算機をバックアップ先候補に選定する，累計バック アップ回数の少ない計算機から順に候補とし, $n$ 台以上 になるまでバックアップ先候補に選定する。このとき, すでに選定された計算機の位置情報と比較し, 遠隔地 と判断されない場合にはバックアップ先候補に選定し ない.

4. バックアップ先候補が $n$ 台より多いとき, 累計バック アップ回数が最多の計算機からバックアップ先を再選定 する.

5. 再選定対象のドライブ空き容量を求め, ドライブ空き容 量の多い順にバックアップ先に選定する。 その後, $n$ 台 の計算機ヘバックアップを行う.

\section{7. 評価実験}

\section{1 実験環境}

実験環境について説明する．表 2 はバックアップ元計算機の 環境, 表 3, 表 4, 表 5 はバックアップ先計算機の環境を示す. また, バックアップ元計算機において, Cassandra を単一ノー ド環境で起動する。 
表 2 実験環境：バックアップ元計算機

\begin{tabular}{|c|c|}
\hline OS & Windows 7 Home Premium 64bit \\
\hline CPU & Intel(R) Core(TM) i7-3770K CPU @ 3.50GHz \\
\hline メモリ & $8.00 \mathrm{~GB}$ \\
\hline IPアドレス & 133.68 \\
\hline ネットワーク情報 & 名古屋工業大学 打矢研究室 \\
\hline データベース & Cassandra 1.2 .5 \\
\hline
\end{tabular}

表 3 実験環境 : バックアップ先計算機 1

\begin{tabular}{|c|c|}
\hline OS & Windows 7 Professional 64bit \\
\hline CPU & Intel(R) Core(TM) i7-3770K CPU @ 3.50GHz \\
\hline メモリ & $8.00 \mathrm{~GB}$ \\
\hline IPアドレス & 133.68 . \\
\hline ネットワーク情報 & 名古屋工業大学 \\
\hline
\end{tabular}

表 4 実験環境 : バックアップ先計算機 2

\begin{tabular}{|c|c|}
\hline OS & Windows 7 Professional 64bit \\
\hline $\mathrm{CPU}$ & Intel(R) Xenon(R) Processor X5650 @ 2.66GHz \\
\hline メモリ & $12.00 \mathrm{~GB}$ \\
\hline IPアドレス & 10.10 .0 (プイベートIPアドレス) \\
\hline ネットワーク情報 & 東北大学 \\
\hline
\end{tabular}

表 5 実験環境 : バックアップ先計算機 3

\begin{tabular}{|c|c|}
\hline OS & Windows 10 Pro 64bit \\
\hline CPU & AMD A8 Pro-7600B R7 \\
\hline メモリ & $16.00 \mathrm{~GB}$ \\
\hline IPアドレス & 202.17. \\
\hline ネットワーク情報 & 千葉工業大学 \\
\hline
\end{tabular}

\section{2 評価実験 1}

第 3 版システム（以降，提案システムと記す）によりバック アップが正しく行われていることを確認しつつ, バックアップ 時の保存容量を計測するための実験を行った.

\subsection{1 実験概要}

表 3 の計算機において，ワークプレースを 3 個起動し，表 2 の計算機から $500 \mathrm{~KB}, 10 \mathrm{MB}, 100 \mathrm{MB}, 1 \mathrm{~GB}$ のサイズの ファイルに対してバックアップを行うときの所要時間を測定す る（図 11）。2 回目のバックアップ時には, 各サイズのファイ ルを編集し，新たに作成したファイルに対してバックアップを 行う（図 12）.

バックアップ条件は分散数 3 , 復元必要数 2 とする. 各サイ ズのファイル，編集の概要， CDCのパラメータについて説明 する.

\section{$500 \mathrm{~KB}$ のファイル}

・初回のバックアップ : スライド 15 枚の pptx ファイル

・2 回目のバックアップ: ファイルの最後に新たにスライド 5 枚を追加した pptx ファイル

\section{$10 \mathrm{MB}$ のファイル}

・初回のバックアップ: 1 分 12 秒の mp4 ファイル

・2 回目のバックアップ：ファイルに 1 分 12 秒の BGM を 追加した mp4 ファイル

$100 \mathrm{MB}$ のファイル

・初回のバックアップ : 25 分 34 秒の mp4 ファイル

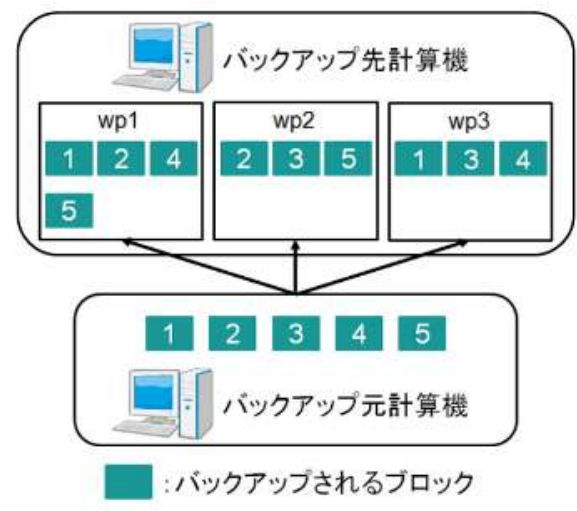

図 11 初回バックアップの様子

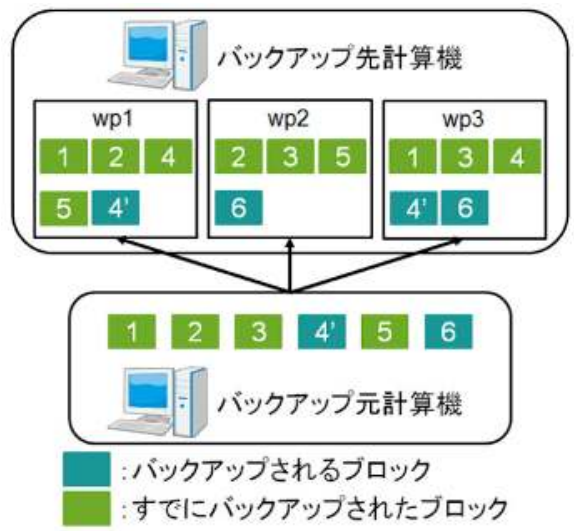

図 122 回目バックアップの様子

・2 回目のバックアップ：ファイルに 4 分 14 秒の BGM を ループ追加した mp4 ファイル

\section{GB のファイル}

・初回のバックアップ : 32 分 15 秒の mp4 ファイル

・2 回目のバックアップ: ファイルに 4 分 14 秒の BGMを ループ追加した mp4 ファイル

\section{CDC のパラメータ}

・ウインドウサイズ： 32 バイト

・最小ブロック長：4096 バイト

・ハッシュ值の下位ビット数：12 ビット

\subsection{2 バックアップの実験結果}

重複排除率の実験結果を表 6 に示す。また，バックアップの 実験結果を表 7 に示す。なお，表中の「先行研究」は第 1 版を 示す.

\section{2 .3 バックアップの考察}

動作検証により，バックアップを問題なく行えていることが 確認できた。表 7 より, 提案システムにおいて重複排除技術が 有効に機能し，デー夕総保存容量が削減できることを確認でき た。これにより, バックアップ先計算機の負担が軽減され，線 形的に増加する保存容量の問題を解決することができた。 その ため，提案システムは有用であると考えられる. 
表 6 提案システムの重複排除率 [\%]

\begin{tabular}{|r|r|r|r|r|}
\hline & $500 \mathrm{~KB}$ & $10 \mathrm{MB}$ & $100 \mathrm{MB}$ & $1 \mathrm{~GB}$ \\
\hline \hline 重複排除率 & 65.7 & 53.1 & 25.3 & 78.1 \\
\hline
\end{tabular}

表 7 デー夕総保存容量

\begin{tabular}{|l|r|r|r|r|}
\hline 測定項目 & $500 \mathrm{~KB}$ & $10 \mathrm{MB}$ & $100 \mathrm{MB}$ & $1 \mathrm{~GB}$ \\
\hline \hline 先行研究 & $2.00 \mathrm{MB}$ & $40.00 \mathrm{MB}$ & $400.00 \mathrm{MB}$ & $4.00 \mathrm{~GB}$ \\
\hline 提案システム & $1.34 \mathrm{MB}$ & $29.38 \mathrm{MB}$ & $349.40 \mathrm{MB}$ & $2.44 \mathrm{~GB}$ \\
\hline
\end{tabular}

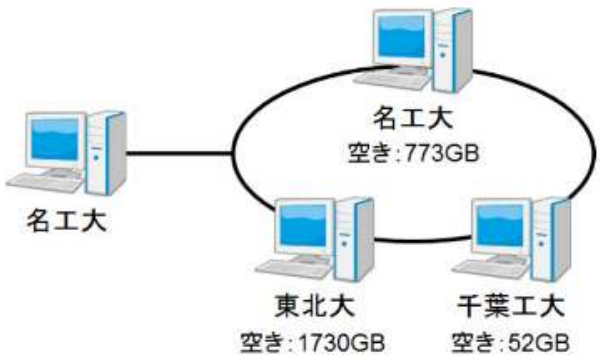

図 13 バックアップ時のネットワーク構成図

表 8 選定されたバックアップ先計算機

\begin{tabular}{|r|r|r|r|}
\hline 初回 & 2 回目 & 3 回目 & 4 回目 \\
\hline \hline 東北大学 & 千葉工業大学 & 東北大学 & 千葉工業大学 \\
\hline
\end{tabular}

\section{3 評価実験 2}

バックアップ先計算機の選定手法により遠隔地へバックアッ プが行われていることを確認するために実験を行った。

\subsection{1 実験概要}

表 3, 表 4, 表 5 の計算機上でワークプレースを起動し, 表 2 の計算機から $500 \mathrm{~KB}, 10 \mathrm{MB}, 100 \mathrm{MB}, 1 \mathrm{~GB}$ のサイズの ファイルに対してファイルの小さい順にバックアップを行うと きのバックアップ先を調査する（図 13）。バックアップ条件は 分散数 1 , 復元必要数 1 とする. 各サイズのファイルの概要に ついては評価実験 1 と同様である.

\subsection{2 実験結果}

実験結果を表 8 に示す

\subsection{3 考察}

表 8 より, バックアップ先計算機が遠隔地の計算機かつ特定 の計算機へ偏らずに選定されることを確認できた。また，初回 ／3回目のバックアップにおいては, ドライブ空き容量をもと にバックアップ先が選定されていることを確認できた。そのた め, バックアップ先計算機の選定手法を導入することは有用で あると考えられる。

\section{4 評価実験 3}

提案システムにより名工大から遠隔地（東北大）へバック アップを行うときの所要時間を評価するために実験を行った。
表 9 提案システム初回バックアップ所要時間 [s]

\begin{tabular}{|l|r|r|r|r|}
\hline 測定項目 & $500 \mathrm{~KB}$ & $10 \mathrm{MB}$ & $100 \mathrm{MB}$ & $1 \mathrm{~GB}$ \\
\hline \hline 分割処理 & 0.04 & 0.13 & 0.86 & 9.00 \\
\hline 重複排除処理 & 0.03 & 0.13 & 0.76 & 6.26 \\
\hline 喑号化処理 & 0.16 & 0.28 & 0.80 & 19.00 \\
\hline 車坛送処理 & 1.79 & 8.95 & 80.51 & 858.61 \\
\hline エージェント処理 & 0.75 & 0.34 & 0.41 & 2.04 \\
\hline バックアップ処理 & 2.77 & 9.83 & 83.34 & 894.91 \\
\hline
\end{tabular}

表 10 提案システム 2 回目のバックアップ所要時間 [s]

\begin{tabular}{|l|r|r|r|r|}
\hline 測定項目 & $500 \mathrm{~KB}$ & $10 \mathrm{MB}$ & $100 \mathrm{MB}$ & $1 \mathrm{~GB}$ \\
\hline \hline 分割処理 & 0.04 & 0.14 & 0.97 & 8.35 \\
\hline 重複排除処理 & 0.04 & 0.20 & 4.31 & 488.18 \\
\hline 暗号化処理 & 0.15 & 0.22 & 0.84 & 11.65 \\
\hline 転送処理 & 1.59 & 5.57 & 54.10 & 189.72 \\
\hline エージェント処理 & 0.30 & 0.33 & 0.48 & 1.46 \\
\hline \hline バックアップ処理 & 2.12 & 6.46 & 60.70 & 699.36 \\
\hline
\end{tabular}

表 11 第 1 版（先行研究）のバックアップ所要時間 [s]

\begin{tabular}{|l|r|r|r|r|}
\hline 測定項目 & $500 \mathrm{~KB}$ & $10 \mathrm{MB}$ & $100 \mathrm{MB}$ & $1 \mathrm{~GB}$ \\
\hline 暗号化処理 & 0.17 & 0.18 & 1.09 & 8.22 \\
\hline 分割処理 & 0.03 & 0.07 & 0.31 & 23.33 \\
\hline 転送処理 & 1.89 & 9.71 & 79.98 & 852.90 \\
\hline エージェント処理 & 0.73 & 0.31 & 0.28 & 1.45 \\
\hline \hline バックアップ処理 & 2.82 & 10.27 & 81.66 & 885.90 \\
\hline
\end{tabular}

\subsection{1 実験概要}

表 3, 表 4, 表 5 の計算機において，ワークプレースを起動 し, 表 2 の計算機から $500 \mathrm{~KB}, 10 \mathrm{MB}, 100 \mathrm{MB}, 1 \mathrm{~GB}$ のサ イズのファイルに対してバックアップを行うときの所要時間を 測定する. 2 回目のバックアップ時には, 各サイズのファイル を編集し，新たに作成したファイルに対してバックアップを行 う．バックアップ条件は分散数 2 , 復元必要数 2 とする。

所要時間を比較するため, 第 1 版に対して初回のバックアッ プのみ同様の実験を行う。また，所要時間を測定するために， バックアップを 3 回行い, 平均を求める。各サイズのファイ ル, 編集の概要, CDC のパラメータについては評価実験 1 と 同様である。

\subsection{2 実験結果}

実験結果を表 9 ，表 $10 ，$ 表 11 に示す.

\subsection{3 考察}

表 9, 表 10 より, バックアップを問題なく行えていることが 確認できた。また，表 9 は初回バックアップ（重複排除適用な し), 表 10 は 2 回目バックアップ（重複排除適用あり）となっ ている。 2 回目のバックアップでは, 重複排除により保存容量 が削減され, この影響でデー夕転送時間が短縮され, 総合的に, バックアップ所要時間が短縮できていることを確認できた

また, 表 11 は, 先行研究のバックアップ（重複排除機能な し）のシステムの動作結果である. 表 10 と表 11 を比べた時, 表 10 の 2 回目バックアップ（重複排除適用あり）の所要時 
間は, 表 11 の先行研究の所要時間よりも短縮されたことが確 認できた。 以上のことから, 提案システムの有用性を確認で きた。

\section{8. おわりに}

本研究では, 複数回バックアップを行うにつれて増加する保 存容量の削減を目的とし，エージェントフレームワーク DASH を用いた個人間分散バックアップシステムを対象に, 重複排除 を導入したシステムの提案を行った。 また，遠隔地の計算機へ バックアップを行うことを目的とし，バックアップ先計算機の 選定手法を導入したシステムの提案と実装を行った。実験で は，提案システムの動作を確認し，第 1 版との所要時間，保存 容量の比較を行い, 提案システムが第 1 版に比べて保存容量 の点で有効であることを確認した。また，重複排除により転送 時間が短縮され，提案システムが第 1 版に比べて所要時間の 点で優れていることも確認した. 最後に, 今後の課題について 示す.

データベースの分散化：現在の提案システムでは，分散データ ベース Cassandra を用いつつ, バックアップ元の計算機でのみ 起動させている. しかし, これでは可用性を確保していない. 従って, Cassandra を拡張し, ファイルだけでなくデータベー スもバックアップが行われるようなシステムを目指す。

システムの長期運用化：現在の提案システムでは, バックアッ プシステムの長期運用が想定されていない，従って，ディスク ドライブ装置とデータベースを連動し，ディスク拡張や更新時 にデータベース内の情報が更新されるシステムを目指す。

\section{参 考 文 献}

[1] M. Shibakawa, T. Uchiya, I. Takumi, and Tetsuo Kinoshita: "Development of the Distributed Backup System Using Multi-Agent Technology," Proc. of the 12th IEEE Int. Conf. on Cognitive Informatics and Cognitive Computing, Jul. 16-18, New York, pp. 268-273, 2013.

[2] 打矢隆弘, 武田敦志, 菅沼拓夫, 木下哲男: “エージェントフレー ムワークにおけけるリポジトリ機構の設計と実装, 情報処理学 会論文誌, Vol.44, No.3, pp. 799-811, 2003.

[3] Java Agent Development Framework: https://jade.tilab.com/ [accessed Oct. 13, 2020]

[4] Open Multi-Agent System: https://www.utc.fr/ barthes/OMAS/ [accessed Oct. 13, 2020]

[5] M. Winikoff: "Jack ${ }^{\mathrm{TM}}$ Intelligent Agents: An Industrial Strength Platform," in Multi-Agent Programming, R. H. Bordini, M. Dastani, J. Dix, A. E. F. Seghrouchni eds., Springer, pp. 175-193, 2005.

[6] CrashPlan Cloud: Endpoint backup \& recovery for the enterprise, http://www.code42.com/crashplan/ [accessed Oct. 13, 2020]

[7] Dropbox: https://www.dropbox.com/ja/ [accessed Oct. 13, 2020]

[8] M. Rabin: "Efficient Dispersal of Information for Security, Load Balancing, and Fault Tolerance," J. of the ACM, Vol.36, No.2, pp. 335-348, 1989.

[9] A. Muthitacharoen, B. Chen, and D. Mazières: "A Lowbandwidth Network File System," Proc. of the 18th ACM Sym. on Operating Systems Principles, Vol.35, No.5, pp. 174-187, 2001.

[10] R. M. Karp and M. O. Rabin: "Effcient Randomized PatternMatching Algorithms," IBM J. of Research and Development, Vol.31, No.2, pp. 249-260, 1987.

[11] Apache Cassandra プロジェクト: http://oss.infoscience.co.jp/ cassandra/ [accessed Oct. 13, 2020]
[12] JPNIC WHOIS Gateway: https://www.nic.ad.jp/ja/whois/jagateway.html [accessed Oct. 13, 2020]

[13] Java API for Google geocoder v3: https://code.google.com/ archive/p/geocoder-java/ [accessed Oct. 13, 2020]

(2020 年 10 月 15 日 受付)

\author{
[問い合わせ先] \\ 干466-8555 愛知県名古屋市昭和区御器所町 \\ 名古屋工業大学大学院工学研究科 \\ 打矢 隆弘 \\ E-mail: t-uchiya@nitech.ac.jp
}

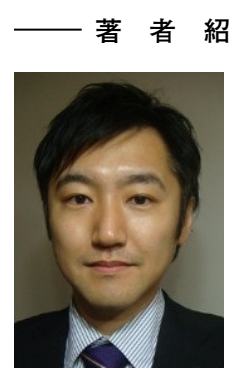

打垁篷胎 [非会員]

名古屋工業大学大学院准教授. 2004 年東北 大学大学院博士後期課程修了. 博士（情報科 学). 2004 年東北大学電気通信研究所助手. 2007 年名古屋工業大学准教授. フランス・コ ンピェーニュ工科大学客員研究員. 東北大学 電気通信研究所共同研究員. 情報処理学会コ ンシューマ・デバイス\&システム研究会運営 委員. 合同エージェントワークショップ\&シ ンポジウム (JAWS) プログラム委員. 2011 年情報処理学会論文誌編集委員会知能グルー プ編集委員. 2013 年情報処理学会論文誌運 営委員会運営委員. 2017 年電子情報通信学会 会誌編集委員. IEEE International Conference on Agents (ICA) Program Committee, International Conference on Principles and Practice of Multi-Agent Systems (PRIMA) Program Committee. 